\title{
Prescrição do Exercício Físico em tempos de Pandemia!
}

Instituição: Uninassau - PE

Email: andrelopes32@yahoo.com.br

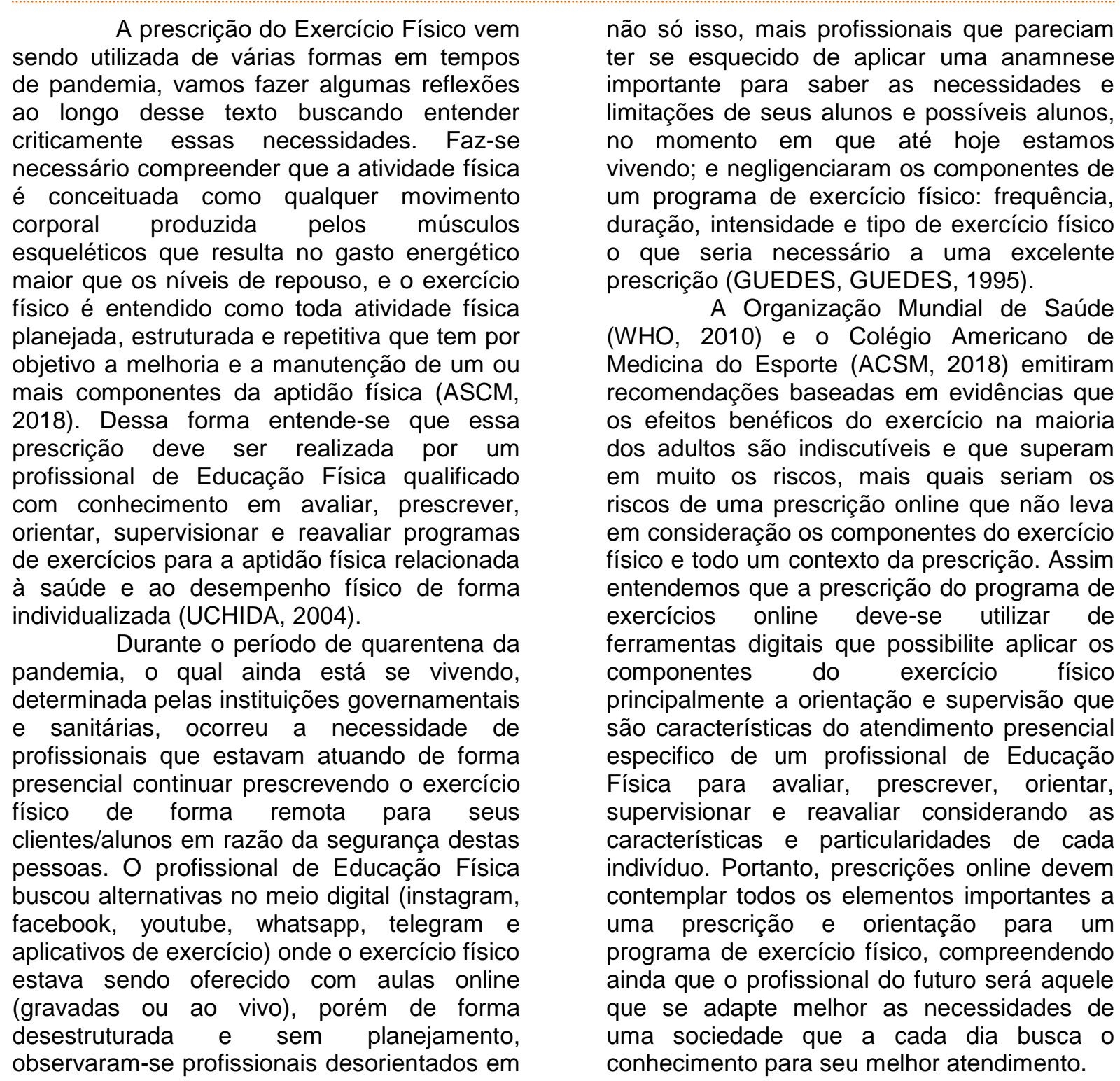
relação à utilização das ferramentas digitais,

\section{REFERÊNCIAS}

AMERICAN COLLEGE OF SPORTS MEDICINE. ACSM's guidelines for exercise testing and prescription. 10th ed. Philadelphia, PA: Wolters Kluwer; 2018. 
GUEDES, D. P.; GUEDES, J.E.R.P. Exercício físico na promoção da saúde. Londrina: Midiograf, 1995.

UCHIDA, M.C. et al. Manual de musculação: uma abordagem teórico-prática do treinamento de força. 2. ed. São Paulo: Phorte, 2004.

WORLD HEALTH ORGANIZAION. Global recommendations on physical activity for health. Geneva, 2010. 